\title{
THE
}

\section{Polycyclic Musks in the Air and Water of the Lower Great Lakes: Spatial Distribution and Volatilization from Surface Waters}

\author{
Carrie A. McDonough \\ Paul A. Helm \\ Derek Muir \\ Gavino Puggioni \\ Rainer Lohmann \\ University of Rhode Island, rlohmann@uri.edu
}

Follow this and additional works at: https://digitalcommons.uri.edu/gsofacpubs

The University of Rhode Island Faculty have made this article openly available.

Please let us know how Open Access to this research benefits you.

This is a pre-publication author manuscript of the final, published article.

Terms of Use

This article is made available under the terms and conditions applicable towards Open Access

Policy Articles, as set forth in our Terms of Use.

\section{Citation/Publisher Attribution}

Mcdonough, C. A., Helm, P. A., Muir, D., Puggioni, G., \& Lohmann, R. (2016). Polycyclic Musks in the Air and Water of the Lower Great Lakes: Spatial Distribution and Volatilization from Surface Waters.

Environmental Science \& Technology, 50(21), 11575-11583.

Available at: http://pubs.acs.org/doi/abs/10.1021/acs.est.6b03657

This Article is brought to you for free and open access by the Graduate School of Oceanography at DigitalCommons@URI. It has been accepted for inclusion in Graduate School of Oceanography Faculty Publications by an authorized administrator of DigitalCommons@URI. For more information, please contact digitalcommons-group@uri.edu. 


\section{Polycyclic Musks in the Air and Water of the Lower}

\section{Great Lakes: Spatial Distribution and Volatilization}

\section{3 from Surface Waters}

4 Carrie A. McDonough ${ }^{1}$, Paul A. Helm ${ }^{2}$, Derek Muir ${ }^{3}$, Gavino Puggioni $^{4}$, Rainer Lohmann ${ }^{1^{*}}$

$5{ }^{1}$ University of Rhode Island, Graduate School of Oceanography, 215 S. Ferry Road,

6 Narragansett, RI 02882, USA

72 Ontario Ministry of the Environment and Climate Change, 125 Resources Road, Toronto,

8 Ontario, Canada M9P 3V6

93 Environment Canada, Aquatic Contaminants Research Division, 867 Lakeshore Road,

10 Burlington, Ontario, Canada L7S 1A1

$11{ }^{4}$ University of Rhode Island, 45 Upper College Road, Kingston, RI 02881, USA

$12{ }^{*}$ Corresponding Author; Email: rlohmann@uri.edu; Phone: 401-874-6612; Fax: 401-874-6811 
Polycyclic musks (PCMs) are synthetic fragrance compounds used in personal care

18 products and household cleaners. Previous studies have indicated that PCMs are introduced to

19 aquatic environments via wastewater and river discharge. Polyethylene passive samplers (PEs)

20 were deployed in air and water during winter 2011 and summer 2012 to investigate the role of

21 population centers as sources of these contaminants to the Great Lakes and determine whether

22 the lakes were acting as sources of PCMs via volatilization. Average gaseous $\sum_{5} \mathrm{PCM}$ ranged

23 from below detection limits ( $<\mathrm{DL})$ to $3.2 \mathrm{ng} / \mathrm{m}^{3}$ on the western shoreline of Lake Erie in Toledo.

24 Average dissolved $\Sigma_{5} \mathrm{PCM}$ ranged from $<\mathrm{DL}$ to $2.6 \mathrm{ng} / \mathrm{L}$ on the southern shore of Lake Ontario

25 near the mouth of the Oswego River. Significant correlations were observed between population

26 density and $\Sigma_{5} \mathrm{PCM}$ in both air and water, with strongest correlations within a 25 and $40 \mathrm{~km}$

27 radius, respectively. At sites where $\mathrm{HHCB}$ was detected it was generally volatilizing, while the

28 direction of AHTN air-water exchange was variable. Volatilization fluxes of HHCB ranged

29 from $11 \pm 6 \mathrm{ng} / \mathrm{m}^{2} /$ day to $341 \pm 127 \mathrm{ng} / \mathrm{m}^{2} /$ day, while air-water exchange fluxes of AHTN ranged

30 from $-3 \pm 2 \mathrm{ng} / \mathrm{m}^{2} /$ day to $28 \pm 10 \mathrm{ng} / \mathrm{m}^{2} /$ day. Extrapolation of average air-water exchange flux

31 values over the surface area of the lakes' coastal boundary zone suggested volatilization may be

32 responsible for the loss of $64-213 \mathrm{~kg} /$ year of dissolved $\Sigma_{5} \mathrm{PCM}$ from the lakes. 
Polycyclic musks (PCMs) are ubiquitous pollutants widely used as additives in personal

39 care products and household cleaners to lend them a long-lasting, pleasing odor. ${ }^{1-3}$ Previous

40 studies have indicated that PCMs are introduced to aquatic environments, including the Great

41 Lakes, via effluent from wastewater treatment plants (WWTPs) and river discharge. ${ }^{3-6}$ One of

42 the most widely used PCMs, 1,3,4,6,7,8-hexahydro-4,6,6,7,8,8-hexamethylcyclopenta-(g)-2-

43 benzopyran (HHCB, or Galaxolide ${ }^{\circledR}$ ), was listed as one of Howard and Muir's top 50 high

44 priority pollutants with persistence and bioaccumulation potential in need of increased

45 monitoring. ${ }^{7}$ The effects of PCMs on aquatic organisms are largely unknown, but they have

46 been found to bioaccumulate ${ }^{8-10}$ and recent studies suggest environmentally relevant

47 concentrations may cause oxidative stress and genetic damage in some organisms. ${ }^{11}$

Polyethylene passive samplers (PEs) are promising tools for measuring hydrophobic

49 organic contaminants (HOCs) at high spatial resolution because they are cost-effective, require

50 no electricity, and are simple to deploy. ${ }^{12}$ PEs sequester the dissolved or gaseous fraction of

51 HOCs from the surrounding water or air over time, allowing measurement of time-integrated

52 concentrations. ${ }^{13-16}$ They have been used to measure a wide variety of HOCs in air and water

53 and to calculate air-water exchange fluxes, ${ }^{17-20}$ but they have not been applied to the study of air-

54 water exchange for PCMs.

55 The use of PEs in this study provided a unique opportunity to measure the truly gaseous

56 and dissolved fraction of PCMs available for air-water exchange and determine whether gaseous

57 PCMs were volatilizing from surface waters in Lake Erie and Lake Ontario. Based on previous

58 work, volatilization may be an important loss route for PCMs in the Great Lakes, ${ }^{4,5}$ but fluxes 
59 had not been determined by simultaneous air and water sampling. In this study, PEs were

60 deployed in air and water during winter 2011 and summer 2012 to (i) measure baseline gaseous

61 and dissolved concentrations of PCMs in and above Lakes Erie and Ontario, (ii) investigate the

62 role of population centers as sources of these contaminants, (iii) determine whether the lakes

63 were acting as sources of PCMs via volatilization, and (iv) explore how PE-derived PCM air-

64 water exchange fluxes respond to non steady-state conditions.

\section{METHODS}

67 Sampler Preparation and Deployment. Prior to deployment, PEs were pre-extracted in solvent

68 and loaded with performance reference compounds (PRCs) dibromobiphenyl,

69 tetrabromobiphenyl, pentabromobiphenyl, naphthalene- $d 8$, pyrene- $d 10$, and benzo(a)pyrene- $d 12$

70 as described previously. ${ }^{19}$ The PE deployment schedule and meteorological parameters,

71 including the number of days each PE was deployed, are summarized in Supporting Information

72 (SI) Table S1. Average temperature and wind speed were determined using data from the

73 nearest available meteorological buoy (Table S2, Figure S1).

74 Shoreline PEs were deployed by trained volunteers as previously described. ${ }^{19}$ Briefly,

75 volunteers hung air PEs inside protective metal bowls at a height of about 1.5 meters, and

76 tethered water PEs to an anchored line so that they would be secured about 1 meter beneath the

77 water's surface. Offshore and nearshore deployments were carried out by workers at

78 Environment Canada and the Ontario Ministry of the Environment, as described previously by

79 Liu et al. ${ }^{17}$ Air PEs were secured in a protective chamber 2 meters above the water's surface on

80 a buoy and water PEs were enclosed within a perforated metal cage and secured to the buoy 
81 about 4 meters below the water's surface. After the PEs were recovered, they were shipped back

82 to the laboratory overnight on ice and frozen until extraction.

83 Extraction and Analysis. PEs from 56 atmospheric deployments (including 9 over-winter

84 deployments) and 39 aqueous deployments were extracted and analyzed. All PEs were spiked

85 with labeled PAHs (acenaphthene- $d 10$, phenanthrene- $d 10$, chrysene- $d 12$, and perylene- $d 12$ ) and

86 extracted for 18-24 hours in pentane, concentrated to $<100 \mu \mathrm{L}$, and spiked with injection

87 standard p-terphenyl- $d 14$. All extracts from aqueous PEs were passed through silica gel/sodium

88 sulfate cleanup columns.

89 Extracts were analyzed for five PCMs: 1,3,4,6,7,8-hexahydro-4,6,6,7,8,8-

90 hexamethylcyclopenta-(g)-2-benzopyran $\quad$ (HHCB,$\quad$ or $\quad$ Galaxolide $\left.{ }^{\circledR}\right), \quad 7$-acetyl-1,1,3,4,4,6-

91 hexamethyl-1,2,3,4-tetrahydronaphthalene (AHTN, or Tonalide ${ }^{\circledR}$ ), 4-acetyl-1,1-dimethyl-6-tert-

92 butylindan (ADBI, or Celestolide ${ }^{\circledR}$ ), 6-acetyl-1,1,2,3,3,5-hexamethylindan (AHMI, or

93 Phantolide ${ }^{\circledR}$ ), 5-acetyl-1,1,2,6-tetramethyl-3-isopropylindane (ATII, or Traesolide ${ }^{\circledR}$ ) and two

94 nitromusks: 1-tert-butyl-3,5-dimethyl-2,4,6-trinitrobenzene (musk xylene) and 4-acetyl-1-tert-

95 butyl-3,5-dimethyl-2,6-dinitrobenzene (musk ketone). This was done using an Agilent 6890 gas

96 chromatograph (GC) with a J\&W Scientific DB-5 MS fused silica capillary column (30 m x 0.25

$97 \mathrm{~mm}$ I.D.) with the injection port set to $275^{\circ} \mathrm{C}$ and helium flow set to $1.9 \mathrm{~mL} / \mathrm{min}$, coupled to an

98 Agilent 5973 mass spectrometric detector (MSD) in electron ionization (EI) mode with ion

99 source at $230{ }^{\circ} \mathrm{C}$, quadrupole at $150{ }^{\circ} \mathrm{C}$, and transfer line at $250{ }^{\circ} \mathrm{C}$. Concentrations were

100 corrected for internal standard recoveries.

101 Quality Control. Every batch of PEs was extracted alongside a laboratory blank and two 102 additional blanks extracted in solvent spiked with all target compounds. Spiked samples were 
103 used to track losses during extraction, concentration, and cleanup. Average recoveries ranged 104 from $79 \%$ for musk xylene to $145 \%$ for musk ketone (Table S3). The relative percent 105 differences (RPD) between ambient concentrations from duplicate samplers are shown in Table 106 S4. For air PEs, the mean RPD was $18 \%$ for HHCB and $21 \%$ for AHTN $(\mathrm{N}=18)$. For water 107 PEs, the mean RPD was $15 \%$ for HHCB and $25 \%$ for AHTN (N=14). Field blanks were sent to each volunteer along with PEs intended for deployment. Field 109 blanks were transported to the sampling site along with other PEs, taken out of their packaging, 110 handled by the volunteer, and then immediately re-packaged and shipped back to the laboratory 111 for analysis. Concentrations of target compounds in deployed PEs were blank-subtracted using 112 the most relevant field blank. For offshore deployments done from research vessels, all field 113 blanks taken during the cruise were averaged and the average field blank value was subtracted 114 from all samples collected.

115 After blank subtraction, the detection limit (DL) in $\mathrm{ng} / \mathrm{g}$ PE was defined as twice the 116 standard deviation for all 11 laboratory blanks, as these samples were representative of the 117 typical variability in background concentrations in the laboratory. Concentrations below 118 detection limits were replaced with zero. Average blank concentrations and detection limits per 119 gram polyethylene are shown in Table S5. For HHCB, which was typically found at greatest 120 concentrations in the blanks, average blank concentrations were $13 \mathrm{ng} / \mathrm{g} \mathrm{PE}, 28 \mathrm{ng} / \mathrm{g} \mathrm{PE}$, and 4 $121 \mathrm{ng} / \mathrm{g}$ PE in laboratory blanks, shoreline volunteer field blanks, and shipboard field blanks, 122 respectively.

123 To better describe the detection limits for PEs, typical DLs in ng/g PE were translated to 124 air and water concentrations using the average percent equilibration for each site type and 
125 assuming an average temperature of $18.85^{\circ} \mathrm{C}$ for summer deployments and $4.85^{\circ} \mathrm{C}$ for winter

126 deployments (Table S6). For air samples, typical ambient detection limits were about $0.9 \mathrm{ng} / \mathrm{m}^{3}$

127 for $\mathrm{HHCB}$ and $0.07 \mathrm{ng} / \mathrm{m}^{3}$ for $\mathrm{AHTN}$ at summer shoreline and offshore sites, and $0.2 \mathrm{ng} / \mathrm{m}^{3}$ for

128 HHCB and $0.01 \mathrm{ng} / \mathrm{m}^{3}$ for AHTN at winter shoreline sites. In water samples, typical detection

129 limits were about $0.6 \mathrm{ng} / \mathrm{L}$ for $\mathrm{HHCB}$ and $0.04 \mathrm{ng} / \mathrm{L}$ for $\mathrm{AHTN}$, with no significant difference

130 between offshore and shoreline samples. Actual detection limits varied from site to site

131 depending on the PE's sampling rate, and all blank subtraction was done using concentrations

132 per weight of polyethylene, before conversion to ambient air and water concentrations.

133 Percent detection for target compounds is presented in Table S7. HHCB and AHTN

134 were found in $15 \%$ and $68 \%$ of all shoreline air PEs deployed in this study and in $38 \%$ and $54 \%$

135 of offshore/nearshore air PEs. In water, HHCB and AHTN were found in $45 \%$ and $60 \%$ of

136 shoreline water PEs and in $47 \%$ and $79 \%$ of offshore water PEs.

137 Physico-chemical Properties. Physico-chemical properties of all target analytes and PRCs are 138 presented in Table S8. PE-air partitioning coefficients $\left(\mathrm{K}_{\mathrm{PEA}}\right)$ were determined from regression 139 with sub-cooled liquid vapor pressure as in Khairy and Lohmann. ${ }^{15}$ PE-water partitioning 140 coefficients $\left(\mathrm{K}_{\mathrm{PEW}}\right)$ were calculated from solubility as in Lohmann. ${ }^{21} \mathrm{~K}_{\mathrm{PEA}}, \mathrm{K}_{\mathrm{PEW}}$, and 141 diffusivity in air $\left(D_{a}\right)$ and water $\left(D_{w}\right)$ for each compound were corrected for each deployment's 142 mean temperature, as detailed further in the SI.

143 Sampling Rates and Ambient Concentrations. To determine ambient concentration $\left(C_{a}\right)$, the 144 concentration in the $\mathrm{PE}\left(\mathrm{C}_{\mathrm{PE}}\right)$ was adjusted for the percent equilibration $(f)$ reached during 145 deployment as in Equation 1. A detailed summary of these calculations is presented in the SI. 146 Briefly, percent loss of each PRC (1-f) was plugged into a generalized exponential model for PE 
147 uptake (Equation 2) to derive a best-fit value for the thickness of the diffusive boundary layer $148\left(\delta_{\mathrm{DBL}}\right)$ using a nonlinear least-squares fitting method adapted from Booij et al. ${ }^{22}$ In Equation 2, $t$ 149 is total deployment time (listed for each deployment in Table S1), $l_{\mathrm{PE}}$ is half the PE thickness, $150 \mathrm{~K}_{\mathrm{PEM}}$ is the PE-matrix partitioning coefficient, and $\mathrm{k}_{\mathrm{o}}$ is the mass transfer coefficient, which 151 represents the reciprocal sum of PE-side resistance $\left(\mathrm{k}_{\mathrm{PE}}^{-1}\right)$, which is dependent on $\mathrm{D}_{\mathrm{PE}}$ and $l_{\mathrm{PE}}$, and 152 environmental matrix-side resistance $\left(\mathrm{k}_{\mathrm{m}}{ }^{-1}\right)$, which is dependent on $\mathrm{D}_{\mathrm{a}}$ or $\mathrm{D}_{\mathrm{w}}$ and $\delta_{\mathrm{DBL}}$. Best-fit $153 \delta_{\mathrm{DBL}}$ values were used to estimate $f$ reached by each PCM during each deployment.

$$
C_{a}=\frac{C_{P E}}{K_{P E A} \cdot f}
$$

$$
f=1-e^{\frac{-t \cdot k_{0} \cdot A_{P E}}{K_{P E M} \cdot V_{P E}}}
$$

Average $f$ values for each PCM are presented in Table S9 and show that HHCB and

157 AHTN generally reached $\geq 95 \%$ equilibrium in both air and water. Average $\delta_{\mathrm{DBL}} \mathrm{S}$ for air 158 boundary layers $\left(\delta_{\mathrm{ABL}}\right)$ were lower for offshore/nearshore PEs $(0.2 \pm 0.1 \mathrm{~mm}$; average \pm stdev $)$ 159 than for shoreline PEs $(1.8 \pm 1.4 \mathrm{~mm}$ in summer and $1.4 \pm 0.5 \mathrm{~mm}$ in winter $)$. This translated to 160 average $\mathrm{HHCB}$ sampling rates of $5.7 \pm 0.9 \mathrm{~m}^{3} /$ day for winter PEs, $6.9 \pm 2.3 \mathrm{~m}^{3} /$ day for shoreline 161 summer PEs, and $13 \pm 0.9 \mathrm{~m}^{3} /$ day for offshore PEs. Average water boundary layer thickness $162\left(\delta_{\mathrm{WBL}}\right)$ was $170 \pm 63 \mu \mathrm{m}$ at shoreline sites and $82 \pm 25 \mu \mathrm{m}$ at offshore sites, which translated to 163 average sampling rates for $\mathrm{HHCB}$ of $16 \pm 3.8 \mathrm{~L} /$ day for shoreline PEs and $9.2 \pm 4.1 \mathrm{~L} /$ day for 164 offshore PEs. 
166 the equation for $f$ to determine typical equilibration times for the PCMs measured in this study.

167 HHCB and AHTN tended to equilibrate within about 25 days in water and 19 days in air, so

168 mean concentrations were representative of these time lengths, though PEs were often deployed

169 for longer. Use of thicker polyethylene sheeting in future deployments would allow for time-

170 integrated concentrations of HHCB and AHTN to be measured over longer time periods.

171 Data Analysis and Statistical Methods. Human population data was extracted from the Global 172 Rural-Urban Mapping Project (GRUMP) Population Count Grid dataset provided by Columbia 173 University ${ }^{23}$ and maps were constructed in ArcMap for Desktop 10.3.1. To find the radii at 174 which population and $\Sigma_{5} \mathrm{PCM}$ correlated most strongly, the model with the lowest residual 175 standard error (RSE) was identified using the ordinary least-squares linear modeling function $176 \mathrm{~lm})$ in R. ${ }^{24}$ Linear models were further refined using the robust linear model $(\mathrm{rlm})$ function in 177 the MASS package in $\mathrm{R}^{25}$ which iteratively fits data to a linear model, weighting outliers 178 depending on their distance from the best-fit line. All presented relationships were found to be 179 statistically significant $(\mathrm{p}<0.01)$ using both approaches. Results were plotted using R package 180 ggplot $2 .{ }^{26}$

181 Air-Water Exchange Calculations. 32 pairs of co-deployed air and water PEs were used to 182 investigate time-integrated air-water exchange fluxes. The direction of exchange was 183 determined by calculating the ratio of fugacity in water to fugacity in air $\left(f_{\mathrm{w}} / f_{\mathrm{a}}\right)$ as in Equation 3, 184 where $\mathrm{C}_{\infty, \mathrm{w}}$ and $\mathrm{C}_{\infty, \mathrm{a}}$ represent the concentration of the compound in the PE once it has reached 185 equilibrium with surrounding water and air, respectively. 
$f_{\mathrm{w}} / f_{\mathrm{a}}>1$ indicates volatilization while $f_{\mathrm{w}} / f_{\mathrm{a}}<1$ indicates absorption. In cases where the concentration in both air and water were $<\mathrm{DL}$, no fugacity ratio was calculated. In cases where

189 the concentration in one medium was $<\mathrm{DL}$, but was $>$ DL in the other medium, a fugacity ratio 190 was calculated by replacing the $<\mathrm{DL}$ value with the DL value, as this resulted in the most 191 conservative estimate for the fugacity ratio (see Figure S2). $\mathrm{C}_{\infty, \mathrm{w}}$ and $\mathrm{C}_{\infty, \mathrm{a}}$ were determined by correcting the concentration in the $\mathrm{PE}\left(\mathrm{C}_{\mathrm{PE}}\right)$ using the 193 calculated percent equilibrium $(f)$ reached by each compound during deployment. In most cases

194 for $\mathrm{AHTN}$ and $\mathrm{HHCB}, \mathrm{C}_{\infty} \sim \mathrm{C}_{\mathrm{PE}}$ because they equilibrated during deployment. The uncertainty 195 in the fugacity ratio was calculated by propagating the uncertainty in the parameters used to 196 calculate $\mathrm{C}_{\infty, \mathrm{a}}$ and $\mathrm{C}_{\infty, \mathrm{w}}$, which is detailed further in the SI. In cases where the fugacity ratio was 197 within one standard deviation from equilibrium, it was not considered significantly different 198 from equilibrium and no flux was calculated. Air-water exchange fluxes $\left(\mathrm{F}_{a / w}\right)$ were calculated using an approach based on the 200 Whitman two-film model ${ }^{27}$ as described in Schwarzenbach et al. ${ }^{28}$ with wind speed's effect on 201 water-side mass transfer determined using a Weibull distribution to account for the non-linearity 202 of the effect of wind speed on mass transfer. ${ }^{29}$ The mass transfer coefficient $\left(v_{\mathrm{a} / \mathrm{w}}\right)$ was 203 multiplied by the concentration gradient as in Equation 4, where $\mathrm{K}_{\mathrm{PEW}, \mathrm{T} 2}$ is the PE-water 204 partitioning coefficient corrected for deployment temperature. Similar approaches have 205 previously been used to estimate air-water exchange fluxes from PE pairs for polychlorinated 206 biphenyls (PCBs), polybrominated diphenyl ethers (PBDEs), and polycyclic aromatic 
207 hydrocarbons (PAHs) in the Great Lakes, ${ }^{20,17,30}$ but PCMs have not been investigated. 208 Uncertainty in exchange fluxes was calculated using the uncertainty of the parameters used to 209 calculate $\mathrm{C}_{\infty, \mathrm{a}}, \mathrm{C}_{\infty, \mathrm{w}}$, and $\mathrm{K}_{\mathrm{PEW}, \mathrm{T} 2}$, and assuming $30 \%$ relative uncertainty in $v_{\mathrm{a} / \mathrm{w}} \cdot{ }^{31}$ Calculations 210 and error propagation are detailed further in the SI.

$$
F_{a / w}=v_{a / w} \cdot \frac{\left(C_{\infty, w}-C_{\infty, a}\right)}{K_{P E W, T 2}}
$$

\section{RESULTS AND DISCUSSION}

215 Dissolved PCM Concentrations. Average dissolved $\Sigma_{5} \mathrm{PCM}$ ranged from $<\mathrm{DL}$ at Cape Vincent

216 (CV) in eastern Lake Ontario to $2.6 \mathrm{ng} / \mathrm{L}$ near the mouth of the Oswego River (OSW) on the 217 southern shoreline of Lake Ontario. Average dissolved concentrations of AHTN and HHCB are 218 shown in Figure 1A.

Average dissolved PCMs are summarized in Table 1. Along the southeastern shore of 220 Lake Erie and the northeastern shore of Lake Ontario, concentrations were similar to offshore 221 levels $\left(\Sigma_{5} \mathrm{PCM}<100 \mathrm{pg} / \mathrm{L}\right)$ and $\mathrm{HHCB}$ was generally $<\mathrm{DL}$, while concentrations were elevated 222 nearer to the urban centers of Toronto and Cleveland and along the southern shore of Lake 223 Ontario. Variation in dissolved $\Sigma_{5} \mathrm{PCM}$ over multiple deployments is shown in Figure S3.

224 Overall, concentrations reported from PEs were similar but lower than previous results:

225 Peck and Hornbuckle measured PCMs in Lake Michigan in 1999-2000 using shipboard active 226 sampling with XAD-2 resin and reported means of $5 \mathrm{ng} / \mathrm{L}$ for HHCB and $1 \mathrm{ng} / \mathrm{L}$ for AHTN. ${ }^{4}$ 
227 Helm et al. estimated concentrations of $0.2-10 \mathrm{ng} / \mathrm{L}$ and $0.1-10 \mathrm{ng} / \mathrm{L}$ for HHCB and AHTN,

228 respectively, east of Toronto in June 2008 using semi-permeable membrane devices (SPMDs). ${ }^{32}$

229 In offshore Lake Ontario, Andresen et al. measured HHCB and AHTN by liquid-liquid 230 extraction of water samples at $2.0 \mathrm{ng} / \mathrm{L}$ and $0.2 \mathrm{ng} / \mathrm{L}$, with concentrations increasing to $7.0 \mathrm{ng} / \mathrm{L}$

231 for HHCB and $0.8 \mathrm{ng} / \mathrm{L}$ for AHTN in Hamilton Harbor. ${ }^{33}$ Concentrations in this study were

232 typically lower than in urban creeks near Toronto (2-1000 ng/L, with lower concentrations $(0.04$

$233-18 \mathrm{ng} / \mathrm{L}$ ) in the less populated Rouge River watershed). ${ }^{5}$ This was expected, as the sites

234 monitored in this study were not as directly representative of upriver source regions.

At sites where both HHCB and AHTN were detected, the ratio of HHCB:AHTN ranged

236 from 7-12, with an average of $10 \pm 2$, which was similar to that reported by Buerge et al. for

237 summertime surface waters in a Swiss lake (HHCB:AHTN 6 - 9) and by Andresen et al. in Lake

238 Ontario in $2005(\sim 10))^{33,34}$ HHCB:AHTN ratios were, in most cases, greater than those

239 measured in source region studies. Buerge et al. estimated that the half-life of HHCB with

240 respect to photolysis in water was about 25 times longer than for AHTN, so increasing

241 HHCB:AHTN ratio in water with distance from source was expected. ${ }^{34}$

242 Nitromusks were not found above a 3:1 signal:noise level in the majority of water 243 samples and were therefore omitted from discussion. Previous studies generally found musk 244 xylene and musk ketone at levels near or below this study's typical detection limits $(19 \mathrm{pg} / \mathrm{L}$ for 245 musk xylene and $225 \mathrm{pg} / \mathrm{L}$ for musk ketone). Peck and Hornbuckle found median concentrations 246 in Lake Michigan of $49 \mathrm{pg} / \mathrm{L}$ for musk xylene and $81 \mathrm{pg} / \mathrm{L}$ for musk ketone, and Andresen et al. 247 measured both nitromusks at about $40 \mathrm{pg} / \mathrm{L}$ in Hamilton Harbor, Lake Ontario. ${ }^{4,33}$ 
248 Gaseous PCM Concentrations. Average summertime $\Sigma_{5} \mathrm{PCM}$ ranged from $<\mathrm{DL}$ at sites in Erie 249 (ERI) and Sheffield Lake (SHF) on the southern Lake Erie shoreline, Prince Edward Point (PEP) 250 in northern nearshore Lake Ontario, and eastern offshore Lake Erie (EERI), to $3.2 \mathrm{ng} / \mathrm{m}^{3} \mathrm{in}$ 251 Toledo (TOL). Concentrations of all gaseous PCMs are summarized in Table 2. Average 252 summertime HHCB and AHTN concentrations are displayed in Figure 1B. Summertime 253 concentrations were lowest at offshore buoy sites $\left(<300 \mathrm{pg} / \mathrm{m}^{3}\right.$, with $\left.\mathrm{HHCB}<\mathrm{DL}\right)$, with the 254 exception of three buoy sites near the Toronto waterfront, where concentrations were comparable 255 to or greater than shoreline sites. Concentrations at shoreline sites were generally greater in the 256 summer than in the winter. Variations in $\Sigma_{5} \mathrm{PCM}$ over multiple deployments are depicted in $257 \quad$ Figure S4.

A possible explanation for the low incidence of detection of HHCB in this study is its 259 short atmospheric lifetime (about 5.3 hours) with respect to photolysis. ${ }^{35}$ HHCB:AHTN ratios in 260 air have previously been shown to decrease with distance from source regions, suggesting that 261 gaseous HHCB may degrade more rapidly than AHTN. ${ }^{36}$ At sites where both AHTN and HHCB 262 were $>$ DL, the average HHCB:AHTN ratio ranged from 3.8 in eastern nearshore Toronto 263 (ETOR) to 6.6 in Toledo (TOL), with an average value of $5 \pm 1$, somewhat similar to ratios 264 measured by Xie et al. in rural Germany (median 3.5). ${ }^{36}$

265 PCMs are relatively volatile $(0.02-1.2 \mathrm{~Pa})^{4}$ compared to other semi-volatile organic 266 contaminants (SVOCs) and a significant fraction of these compounds $(>80 \%)$ is typically found 267 in the gaseous phase, suggesting that PE-derived concentrations should match those from other 268 air sampling techniques. Indeed, results from previous studies were similar: Peck and 269 Hornbuckle measured gas-phase PCMs in 1999-2001 using XAD-2 resin throughout the Great 
270 Lakes and found average urban $\sum_{2} \mathrm{PCM}(\mathrm{AHTN}+\mathrm{HHCB})$ around $1-5 \mathrm{ng} / \mathrm{m}^{3}$ with mean offshore

271 Lake Erie and Lake Ontario concentrations $<0.5 \mathrm{ng} / \mathrm{m}^{3} \cdot{ }^{37}$ Furthermore, average $\sum_{2} \mathrm{PCM}$

272 concentrations in Toronto nearshore air measured in this study $\left(1.6-3.1 \mathrm{ng} / \mathrm{m}^{3}\right)$ were comparable

273 to those measured by Melymuk et al. during 2007-2008 using polyurethane foam (PUF) samplers

274 within $10 \mathrm{~km}$ of the Toronto central business district $\left(0.89-3.5 \mathrm{ng} / \mathrm{m}^{3}\right) .{ }^{38}$

275 As in water, the nitromusks were not found above 3:1 signal:noise levels in the majority

276 of air samples and were therefore omitted from discussion. In previous work by Peck and

277 Hornbuckle in the lower Great Lakes region, nitromusks in air were found above method

278 reporting limits only intermittently and at levels under $80 \mathrm{pg} / \mathrm{m}^{3} .{ }^{37}$

279 Correlation of PCM concentrations with Population Density. Previous studies have 280 identified population centers as sources of gaseous PCMs to ambient air ${ }^{37}$ and have shown

281 correlations between population density and PCMs in air and water. ${ }^{34,39,40}$ To investigate the 282 relationship between PCMs and population density in the lower Great Lakes, average 283 summertime concentrations were compared to population within 2 to $50 \mathrm{~km}$ of each site. The 284 strongest correlations found for gaseous and dissolved PCMs are displayed in Figure 2.

$285 \quad$ Gaseous $\Sigma_{5} \mathrm{PCM}$ exhibited significant $(\mathrm{p}<0.01)$ correlation with population within a 15$28650 \mathrm{~km}$ radius of each site. The correlation was strongest when considering population within 25 $287 \mathrm{~km}(\mathrm{p}<0.001 ; \mathrm{SE}=0.33 ; \mathrm{N}=22)$. The two locations with the greatest residuals were Toledo 288 (TOL) and Cleveland Edgewater (CLE), both of which exhibited greater gaseous $\Sigma_{5} \mathrm{PCM}$ than 289 would be predicted from population based on the presented regression. This suggests elevated 290 concentrations in these areas may be caused by nearby point sources not representative of the 291 surrounding region. 
Dissolved $\Sigma_{5} \mathrm{PCM}$ exhibited significant $(\mathrm{p}<0.01)$ correlation with population within a

$29320-40 \mathrm{~km}$ radius of each site, with the strongest correlation observed when considering 294 population within $40 \mathrm{~km}(\mathrm{p}<0.005 ; \mathrm{SE}=0.26 ; \mathrm{N}=20)$. The strong correlation at such a large 295 radius may be because spatial distributions are influenced by wastewater outfalls and river 296 mouths, both of which are point sources that represent a much larger area's population (the 297 watershed). Concentrations near the mouth of Oswego River exhibited the greatest residuals, 298 again suggesting a nearby point source.

299 River and Wastewater Discharge. Dissolved PCMs were elevated at many shoreline sites 300 impacted by nearby WWTPs designated as major dischargers by the US Environmental 301 Protection Agency (EPA) National Pollutant Discharge Elimination System (NPDES), ${ }^{41}$ many of 302 which discharged directly into the lakes. More details on sites with elevated concentrations and 303 possible sources are included in the SI.

304 Air-Water Exchange. Fugacity Ratios. Fugacity ratios for all air-water PE pairs are displayed 305 in Table S10 and depicted in Figure S2. At all sites where HHCB was detected in air and/or 306 water, fugacity ratios suggested it was volatilizing out of surface waters. Fugacity ratios for 307 AHTN also suggested volatilization from surface waters near Toronto and along the southern 308 shore of Lake Ontario, though AHTN was near equilibrium or absorbed into surface waters at 309 some other sites.

310 The greatest fugacity ratios for both AHTN $\left(f_{w} / f_{a}=7\right)$ and HHCB $\left(f_{w} / f_{a}=18\right)$ were 311 calculated for the PE pair from the late-summer deployment near the mouth of the Oswego River 312 (OSW), during which greater dissolved PCMs were measured than during any other deployment $313\left(\Sigma_{5} \mathrm{PCM}=4.8 \mathrm{ng} / \mathrm{L}\right)$. Fugacity ratios were generally not significantly different from equilibrium 
314 at sites on the southeastern shore of Lake Erie (ERI, DUN, BUF), the northeastern Lake Ontario

315 shoreline/nearshore (CV, PEP, CHB), or at the offshore sites (CERI, EERI).

316 PE-Derived Air-Water Exchange Fluxes at Non-Steady-State Conditions. Values of $v_{a / w}$

317 calculated for HHCB and AHTN ranged from 4.5-8.8 cm/day, which was somewhat slower than

318 rates for PCBs calculated by Liu et al. (15-63 cm/day) and within the range for 4-ring PAHs

319 calculated by McDonough et al. (1-16 cm/day). ${ }^{20}$ These rates were used along with mass

320 transfer coefficients for PE uptake $\left(\mathrm{k}_{0}\right)$ of HHCB from air (181-6,905 $\mathrm{cm} /$ day) and water (14-47

$321 \mathrm{~cm} /$ day) to determine how air-water exchange fluxes derived from co-deployed air and water

322 PEs compared to actual values in scenarios where concentrations in air and water are not at

323 steady state.

324 A model was written in R in which air and water concentrations of HHCB were set to 325 vary every 6 hours over 100 days. In Scenario 1, both air and water concentrations fluctuated 326 randomly between minimum and maximum values based on realistic concentration ranges from 327 this and previous studies $\left(1-6 \mathrm{ng} / \mathrm{m}^{3}\right.$ in air; $0.5-8 \mathrm{ng} / \mathrm{L}$ in water). In Scenario 2, air 328 concentrations fluctuated randomly around a steadily increasing mean from 5 to $12 \mathrm{ng} / \mathrm{m}^{3}$ and 329 water concentrations declined from 6 to $1 \mathrm{ng} / \mathrm{L}$, also with random fluctuations, resulting in a 330 reversal of the flux direction during the deployment. The air-water exchange flux $\left(\mathrm{F}_{\mathrm{aw}}\right)$ at each 331 time point was calculated from the simulated air and water concentrations at that time.

332 At each time point, the mass of HHCB accumulated in air and water PEs in response to 333 the fluctuating ambient concentrations was computed, and the PE-derived air-water exchange 334 flux $\left(\mathrm{F}_{\mathrm{aw}, \mathrm{PE}}\right)$ was calculated based on the concentrations of HHCB in the co-deployed PEs at that 335 time. $\mathrm{F}_{\mathrm{aw}}$ was then compared to $\mathrm{F}_{\mathrm{aw}, \mathrm{PE}}$ by calculating the RPD between the two values. An 
336 example from Scenario 2, in which $\mathrm{F}_{\text {aw }}$ decreased throughout the simulated deployment, is

337 displayed in Figure 3. $\mathrm{F}_{\mathrm{aw}, \mathrm{PE}}$ is shown to steadily decline over the deployment along with $\mathrm{F}_{\mathrm{aw}}$,

338 but $\mathrm{F}_{\mathrm{aw}, \mathrm{PE}}$ does not capture rapid day-to-day changes in the flux and appears to lag behind $\mathrm{F}_{\mathrm{aw}}$ by

339 about 20 days. A similar figure is shown for Scenario 1 in Figure S5.

340 Each scenario was run 100 times, and each time the RPD between $\mathrm{F}_{\mathrm{aw}, \mathrm{PE}}$ and $\mathrm{F}_{\mathrm{aw}}$ after

341100 days of deployment was recorded. Results are presented in Table 3 as the mean RPD

342 between $F_{a w, P E}$ and three values: $F_{a w}$ on the last day of the simulated deployment (Day 100), the

343 average $\mathrm{F}_{\mathrm{aw}}$ over the typical equilibration time for $\mathrm{HHCB}$ (defined as 22 days, the average of air

344 and water PE equilibrium times), and the average $F_{a w}$ over the entire 100-day deployment.

345 Results show that PE-derived exchange fluxes provide a good estimate of mean $\mathrm{F}_{\text {aw }}$ over the last

34622 days in both scenarios, though they were not always representative of instantaneous fluxes the

347 day they were recovered, or of average fluxes over the entire deployment period.

Table 3 also shows RPDs determined by comparison of "actual" fluxes $\left(\mathrm{F}_{\mathrm{aw}}\right)$ and fluxes

349 that would be derived from weekly grab samples. Grab samples were simulated by taking values

350 of the "actual" concentrations of PCMs in air and water once a week, calculating instantaneous

351 exchange fluxes, and averaging these values over the 100-day deployment, or over the last 22

352 days. Results suggest that $\mathrm{F}_{\mathrm{aw}, \mathrm{PE}}$ is more representative of the mean $\mathrm{F}_{\mathrm{aw}}$ over the last 22 days

353 than taking 3 weekly grab samples, while weekly grab samples are more appropriate for

354 capturing mean flux over 100 days in cases where the exchange flux changes steadily over time,

355 as in Scenario 2. In summary, PEs resulted in a very good approximation of the actual air-water

356 exchange flux during the compounds' equilibration time window, in some cases superior to

357 weekly grab sampling. 
PCM Air-Water Exchange Fluxes. Air-water exchange mass transfer coefficients and exchange

359 fluxes for all PE pairs with fugacity ratios significantly different from equilibrium are provided

360 in Tables S11 and S12. Figure 4 shows air-water exchange fluxes calculated for HHCB and

361 AHTN in $\mathrm{ng} / \mathrm{m}^{2} /$ day during each deployment for which data was available. As demonstrated in

362 the previous section, these fluxes were representative of time-averaged air-water exchange fluxes

363 over the last 3 weeks prior to sampler recovery.

364 Volatilization fluxes of HHCB and AHTN ranged from $11 \pm 6 \mathrm{ng} / \mathrm{m}^{2} /$ day and $-3 \pm 2$

$365 \mathrm{ng} / \mathrm{m}^{2} /$ day during the first deployment near the shore of Cleveland, OH (CLE) to $341 \pm 127$

$366 \mathrm{ng} / \mathrm{m}^{2} /$ day and $28 \pm 10 \mathrm{ng} / \mathrm{m}^{2} /$ day during late summer near the mouth of Oswego River (OSW).

367 Few previous measurements of PCM air-water exchange fluxes are available for comparison.

368 Xie et al. measured median net air-water volatilization of $27 \mathrm{ng} / \mathrm{m}^{2} /$ day and $14 \mathrm{ng} / \mathrm{m}^{2} /$ day for

369 HHCB and AHTN in the North Sea, and measured net deposition of both compounds in the 370 Arctic. $^{36}$

\section{IMPLICATIONS}

373 Results from this study suggest that WWTPs may be responsible for influencing spatial

374 distributions of dissolved PCMs in the lower Great Lakes, and that PCMs in the lakes were

375 volatilizing from surface waters at many locations near urbanized shorelines. Previous studies of

376 the Great Lakes region have estimated that volatilization is an important loss route for dissolved

377 PCMs. Melymuk et al. estimated that volatilization removes $31 \%$ of total inputs of PCMs from

378 the Toronto area, about $210 \pm 120 \mathrm{~kg} / \mathrm{yr}$, from Lake Ontario. ${ }^{5}$ Peck and Hornbuckle estimated that

379 volatilization was responsible for the loss of about $290 \mathrm{~kg} / \mathrm{yr}$ of PCMs from Lake Michigan. ${ }^{4}$ 
Volatilization fluxes in this study were driven by elevated dissolved concentrations at

381 shoreline and nearshore sites. These elevated concentrations were expected to be entrained in

382 the nearshore coastal boundary zone, which extends from the shoreline to where the depth of the

383 lake exceeds that of the thermocline. ${ }^{42}$ To estimate total losses of dissolved PCMs from the

384 lakes via volatilization, fluxes were averaged over the estimated surface area of the urbanized

385 coastal boundary zone.

The surface area of the Lake Ontario coastal boundary zone was estimated to be 6500

$387 \mathrm{~km}^{2}$ by extracting the area with depth shallower than 50 meters using GIS data from the Great 388 Lakes Commission's Great Lakes Information Network (GLIN), as shown in Figure S6. The 389 coastal boundary zone in Lake Erie was more difficult to define, as most of the lake is quite 390 shallow and it does not develop a pronounced seasonal thermocline as in Lake Ontario. From 391 GLIN data, the surface area of Lake Erie shallower than $20 \mathrm{~m}$ was estimated to be $15200 \mathrm{~km}^{2}$.

393 over the coastal boundary zone. Assuming fluxes of this magnitude occurred over $30 \%-100 \%$

394 the total coastal boundary zone and that fluxes of this magnitude occur all year long, we 395 estimated that $41-138 \mathrm{~kg} / \mathrm{year} \Sigma_{5} \mathrm{PCM}$ could be lost to volatilization in Lake Ontario. Lake Erie 396 data yielded an average $\Sigma_{5} \mathrm{PCM}$ flux of $13 \mathrm{ng} / \mathrm{m}^{2} /$ day, suggesting that $22-74 \mathrm{~kg} / \mathrm{year} \Sigma_{5} \mathrm{PCM}$ 397 could be lost to volatilization in Lake Erie. This may be an overestimate, as fluxes could be 398 lower in the winter, when the surface waters freeze and lower temperatures drive down PCM 399 vapor pressure, but the absence of wintertime dissolved concentration data prohibited flux 400 calculations for these months. While these estimations are based on temporally- and spatially401 limited data, they are of a similar magnitude to those estimated in previous Great Lakes studies, 
402 and suggest that volatilization may be a significant loss process for dissolved PCMs in this

403 region.

404 ASSOCIATED CONTENT

405 Supporting Information. Additional figures and tables are available in the Supporting

406 Information along with explanations of calculations to derive percent equilibration and propagate

407 uncertainty in fugacity ratios. This material is available free of charge via the Internet at

408 http://pubs.acs.org.

409

410 AUTHOR INFORMATION

411 Corresponding Author

412 * Rainer Lohmann: rlohmann@uri.edu

\section{Author Contributions}

414 The manuscript was written through contributions of all authors. All authors have given

415 approval to the final version of the manuscript.

\section{ACKNOWLEDGMENTS}

418 We would like to acknowledge funding from the US EPA Great Lakes Restoration Initiative 419 (GLRI) GLAS \#00E00597-0, project officer Todd Nettesheim. We would also like to express 420 our gratitude to Professor Peter August (URI) for assistance with GIS analysis, David Adelman

421 (URI) for sampler preparation and field deployment logistics, Camilla Teixeira and the field staff 422 of the Emergencies, Operational Analytical Laboratories, and Research Support group 
423 (Environment Canada Burlington) for open-lake PE deployments, Great Lakes Unit field staff of 424 the Ontario Ministry of the Environment and Climate Change for Lake Ontario nearshore 425 deployments, and all of the volunteers who deployed PEs throughout the Great Lakes region.

426

427

428

429

430

431

432

433

434

435

436

437

438

439

440 


\section{REFERENCES}

443 (1) Rimkus, G. G. Polycyclic musk fragrances in the aquatic environment. Toxicol. Lett. 1999, 111, 37-56, DOI:10.1016/S0378-4274(99)00191-5.

(2) Hornbuckle, K.; Peck, A. M. Environmental Sources, Occurrence, and Effects of

(3) Homem, V.; Silva, J. A.; Ratola, N.; Santos, L.; Alves, A. Long lasting perfume--a review

(4) Peck, A. M.; Hornbuckle, K. C. Synthetic musk fragrances in Lake Michigan. Environ.

(5) Melymuk, L.; Robson, M.; Csiszar, S. A.; Helm, P. A.; Kaltenecker, G.; Backus, S.; Bradley, L.; Gilbert, B.; Blanchard, P.; Jantunen, L.; Diamond, M. L. From the city to the Lake: loadings of PCBs, PBDEs, PAHs and PCMs from Toronto to Lake Ontario. Environ. Sci. Technol. 2014, 48, 3732-3741, DOI:10.1021/es403209z.

(6) Bester, K. Polycyclic musks in the Ruhr catchment area--transport, discharges of waste water, and transformations of HHCB, AHTN and HHCB-lactone. J. Environ. Monit. 2005, 7, 43-51, DOI:10.1039/b409213a.

(7) Howard, P. H.; Muir, D. C. G. Identifying New Persistent and Bioaccumulative Organics Among Chemicals in Commerce. Environ. Sci. Technol. 2010, 44, 2277-2285, DOI:10.1021/es903383a.

(8) Gatermann, R.; Biselli, S.; Hühnerfuss, H.; Rimkus, G. G.; Hecker, M.; Karbe, L. Synthetic musks in the environment. Part 1: Species-dependent bioaccumulation of polycyclic and nitro musk fragrances in freshwater fish and mussels. Arch. Environ. Contam. Toxicol. 2002, 42, 437-446, DOI:10.1007/s00244-001-0041-2.

(9) O'Toole, S. O.; Metcalfe, C. Synthetic Musks in Fish from Urbanized Areas of the Lower Great Lakes , Canada. J. Gt. Lakes Res. 2006, 32, 361-369, DOI:10.3394/03801330(2006)32[361:SMIFFU]2.0.CO;2.

(10) Reiner, J. L.; Kannan, K. Polycyclic Musks in Water, Sediment, and Fishes from the Upper Hudson River, New York, USA. Water, Air, Soil Pollut. 2010, 214, 335-342, DOI:10.1007/s11270-010-0427-8.

(11) Parolini, M.; Magni, S.; Traversi, I.; Villa, S.; Finizio, A.; Binelli, A. Environmentally relevant concentrations of galaxolide (HHCB) and tonalide (AHTN) induced oxidative and genetic damage in Dreissena polymorpha. J. Hazard. Mater. 2015, 285, 1-10, DOI:10.1016/j.jhazmat.2014.11.037.

(12) Lohmann, R.; Muir, D. Global Aquatic Passive Sampling (AQUA-GAPS): using passive samplers to monitor POPs in the waters of the world. Environ. Sci. Technol. 2010, 44, 860-864, DOI:10.1021/es902379g.

(13) Adams, R. G.; Lohmann, R.; Fernandez, L. A.; Macfarlane, J. K.; Gschwend, P. M. 
Polyethylene Devices: Passive Samplers for Measuring Dissolved Hydrophobic Organic Compounds in Aquatic Environments. Environ. Sci. Technol. 2007, 41, 1317-1323, DOI:10.1021/es0621593.

(14) Lohmann, R.; Booij, K.; Smedes, F.; Vrana, B. Use of passive sampling devices for monitoring and compliance checking of POP concentrations in water. Environ. Sci. Pollut. Res. Int. 2012, 19, 1885-1895, DOI:10.1007/s11356-012-0748-9.

(15) Khairy, M. A.; Lohmann, R. Field calibration of low density polyethylene passive samplers for gaseous POPs. Environ. Sci. Process. Impacts 2014, 16, 414-421, DOI:10.1039/c3em00493g.

(16) Bartkow, M. E.; Booij, K.; Kennedy, K. E.; Müller, J. F.; Hawker, D. W. Passive air sampling theory for semivolatile organic compounds. Chemosphere 2005, 60, 170-176, DOI:10.1016/j.chemosphere.2004.12.033.

(17) McDonough, C. A.; Khairy, M. A.; Muir, D. C. G.; Lohmann, R. Significance of population centers as sources of gaseous and dissolved PAHs in the lower Great Lakes. Environ. Sci. Technol. 2014, 48, 7789-7797, DOI:10.1021/es501074r.

(18) Khairy, M.; Muir, D.; Teixeira, C.; Lohmann, R. Spatial Trends, Sources, and Air-Water Exchange of Organochlorine Pesticides in the Great Lakes Basin Using Low Density Polyethylene Passive Samplers. Environ. Sci. Technol. 2014, 48, 9315-9324, DOI:10.1021/es501686a.

(19) Tidwell, L. G.; Allan, S. E.; Connell, S. G. O.; Hobbie, K. A.; Smith, B. W.; Kim, A. PAH and OPAH Air and Water Exchange during the Deepwater Horizon Incident. Environ. Sci. Technol. 2016, 50, 7489-7497, DOI:10.1021/acs.est.6b02784.

(20) Liu, Y.; Wang, S.; McDonough, C. A.; Khairy, M.; Muir, D. C. G.; Helm, P. A.; Lohmann, R. Gaseous and freely-dissolved PCBs in the lower Great Lakes based on passive sampling: spatial trends and air-water exchange. Environ. Sci. Technol. 2016, 50, 4932-4939, DOI:10.1021/acs.est.5b04586.

(21) Lohmann, R. Critical review of low-density polyethylene's partitioning and diffusion coefficients for trace organic contaminants and implications for its use as a passive sampler. Environ. Sci. Technol. 2012, 46, 606-618, DOI:10.1021/es202702y.

(22) Booij, K.; Smedes, F. An Improved Method for Estimating in Situ Sampling Rates of Nonpolar Passive Samplers. Environ. Sci. Technol. 2010, 44, 6789-6794, DOI:10.1021/es101321v.

(23) Center for International Earth Science Information Network (CIEISIN); Columbia University; International Food Policy Research Institute (IFPRI); The World Bank; Centro Internacional de Agricultura Tropical (CIAT). Global Rural-Urban Mapping Project, Version $\quad 1 \quad$ (GRUMPv1): $\quad$ Population Count Grid http://sedac.ciesin.columbia.edu/data/set/grump-v1-population-count.

(24) R Core Team. R: A language and environment for statistical computing (version 3.1.0), 2014.

(25) Venables, W. N.; Ripley, B. D. Modern Applied Statistics with S. Fourth Edition.; Springer: New York, New York, USA, 2002. 
(26) Wickham, H. ggplot2: Elegant Graphics for Data Analysis; Springer-Verlag: New York, New York, USA, 2009.

(27) Whitman, W. G. A Preliminary Experimental Confirmation of the Two-Film Theory of Gas Absorption. Chem. Metall. Eng. 1923, 29, 146-148, DOI:10.1016/00179310(62)90032-7.

(28) Schwarzenbach, R. P.; Gschwend, P. M.; Imboden, D. M. Environmental Organic Chemistry; 2nd ed.; Wiley Interscience, 2002.

(29) Zhang, H.; Eisenreich, S. J.; Franz, T. R.; Baker, J. E.; Offenberg, J. H. Evidence for Increased Gaseous PCB Fluxes to Lake Michigan from Chicago. Environ. Sci. Technol. 1999, 33, 2129-2137, DOI:10.1021/es981073+.

(30) Ruge, Z.; Muir, D.; Helm, P.; Lohmann, R. Concentrations, trends, and air-water exchange of PAHs and PBDEs derived from passive samplers in Lake Superior in 2011. Environ. Sci. Technol. 2015, 49, 13777-13786, DOI:10.1021/acs.est.5b02611.

(31) Rowe, M. D.; Perlinger, J. A. Micrometeorological measurement of hexachlorobenzene and polychlorinated biphenyl compound air-water gas exchange in Lake Superior and comparison to model predictions. Atmos. Chem. Phys. 2012, 12, 4607-4617, DOI:10.5194/acp-12-4607-2012.

(32) Helm, P. A.; Howell, E. T.; Li, H.; L. Metcalfe, T.; M. Chomicki, K.; D. Metcalfe, C. Influence of nearshore dynamics on the distribution of organic wastewater-associated chemicals in Lake Ontario determined using passive samplers. J. Great Lakes Res. 2012, 38, 105-115, DOI:10.1016/j.jglr.2012.01.005.

(33) Andresen, J. A.; Muir, D.; Ueno, D.; Darling, C.; Theobald, N.; Bester, K. Emerging pollutants in the North Sea in comparison to Lake Ontario, Canada, data. Environ. Toxicol. Chem. 2007, 26, 1081-1089, DOI:10.1897/06-416R.1.

(34) Buerge, I. J.; Buser, H.; Mu, M. D.; Poiger, T.; Wa, C. Behavior of the Polycyclic Musks HHCB and AHTN in Lakes, Two Potential Anthropogenic Markers for Domestic Wastewater in Surface Waters. Environ. Sci. Technol. 2003, 37, 5636-5644, DOI:10.1021/es0300721.

(35) Aschmann, S. M.; Arey, J.; Atkinson, R.; Simonich, S. L. Atmospheric lifetimes and fates of selected fragrance materials and volatile model compounds. Environ. Sci. Technol. 2001, 35, 3595-3600, DOI:10.1021/es010685i.

(36) Xie, Z.; Ebinghaus, R.; Temme, C.; Heemken, O.; Ruck, W. Air-sea exchange fluxes of synthetic polycyclic musks in the North Sea and the Arctic. Environ. Sci. Technol. 2007, 41, 5654-5659, DOI:10.1021/es0704434.

(37) Peck, A.; Hornbuckle, K. Synthetic musk fragrances in urban and rural air of Iowa and the Great Lakes. Atmos. Environ. 2006, 40, 6101-6111, DOI:10.1016/j.atmosenv.2006.05.058.

(38) Melymuk, L.; Robson, M.; Helm, P. A.; Diamond, M. L. PCBs, PBDEs, and PAHs in Toronto air: spatial and seasonal trends and implications for contaminant transport. Sci. Total Environ. 2012, 429, 272-280, DOI:10.1016/j.scitotenv.2012.04.022.

(39) Melymuk, L.; Robson, M.; Helm, P. A.; Diamond, M. L. Application of land use 
regression to identify sources and assess spatial variation in urban SVOC concentrations. Environ. Sci. Technol. 2013, 47, 1887-1895, DOI:10.1021/es3043609.

(40) Lu, B.; Feng, Y.; Gao, P.; Zhang, Z.; Lin, N. Distribution and fate of synthetic musks in the Songhua River, Northeastern China: influence of environmental variables. Environ. Sci. Pollut. Res. Int. 2015, 22, 9090-9099, DOI:10.1007/s11356-014-3973-6.

(41) US EPA. US EPA Discharge Monitoring Report (DMR) Pollutant Loading Tool, v 1.0 https://cfpub.epa.gov/dmr/index.cfm.

(42) Rao, Y. R.; Schwab, D. J. Laurentian Great Lakes, Interaction of Coastal and Offshore Waters. Encyclopedia of Lakes and Reservoirs, 2012, 479-485. 
FIGURES AND TABLES

Table 1. Average dissolved PCMs (pg/L) summarized regionally

\begin{tabular}{lcccccc} 
& $\mathbf{N}^{\mathbf{a}}$ & ADBI & AHMI & ATII & HHCB & AHTN \\
\hline Toronto Waterfront Nearshore & 3 & $1.1 \pm 0.7$ & $2.2 \pm 0.7$ & $37 \pm 6.6$ & $1625 \pm 242$ & $162 \pm 32$ \\
Southern L. Ontario Shoreline & 3 & $1.2 \pm 0.8$ & $2.4 \pm 1.3$ & $28 \pm 33$ & $1363 \pm 827$ & $134 \pm 66$ \\
Greater Cleveland Shoreline/Nearshore & 3 & $1.5 \pm 0.9$ & $3.9 \pm 2.2$ & $29 \pm 13$ & $697 \pm 222$ & $72 \pm 19$ \\
Southeast L. Erie Shoreline & 3 & $0.1 \pm 0.2$ & $0.8 \pm 0.3$ & $3.0 \pm 5.1$ & $23 \pm 39$ & $16 \pm 7.9$ \\
Northeast L. Ontario Nearshore & 3 & $<\mathrm{DL}$ & $0.4 \pm 0.4$ & $2.1 \pm 2.0$ & $<\mathrm{DL}$ & $14 \pm 12$ \\
Offshore L. Erie and L. Ontario & 5 & $0.9 \pm 1.2$ & $2.5 \pm 3.8$ & $16 \pm 21$ & $<\mathrm{DL}$ & $28 \pm 18$ \\
\hline
\end{tabular}

$591{ }^{a} \mathrm{~N}$ is the number of sites of each type.

594 Table 2. Average gaseous PCMs $\left(\mathrm{pg} / \mathrm{m}^{3}\right)$ grouped by site type

\begin{tabular}{lcccccc} 
& N $^{\text {a }}$ & ADBI & AHMI & ATII & HHCB & AHTN \\
\hline Summer (May - November) & & & & & & \\
\hline Offshore/Nearshore Buoys & 5 & $2.1 \pm 4.6$ & $2.2 \pm 4.9$ & $47 \pm 106$ & $<\mathrm{DL}$ & $5.4 \pm 12$ \\
Toronto Waterfront Nearshore Buoys & 3 & $0.6 \pm 1.0$ & $24 \pm 17$ & $493 \pm 69$ & $1529 \pm 591$ & $302 \pm 88$ \\
L. Erie and L. Ontario Shoreline & 14 & $2.8 \pm 6.3$ & $11 \pm 9.5$ & $100 \pm 189$ & $357 \pm 836$ & $149 \pm 159$ \\
\hline Winter (December - April) & & & & & & \\
\hline L. Erie and L. Ontario Shoreline & 9 & $0.2 \pm 0.6$ & $0.8 \pm 1.5$ & $22 \pm 44$ & $29 \pm 87$ & $17 \pm 19$ \\
\hline
\end{tabular}

${ }^{\mathrm{a}} \mathrm{N}$ is the number of sites of each type. 

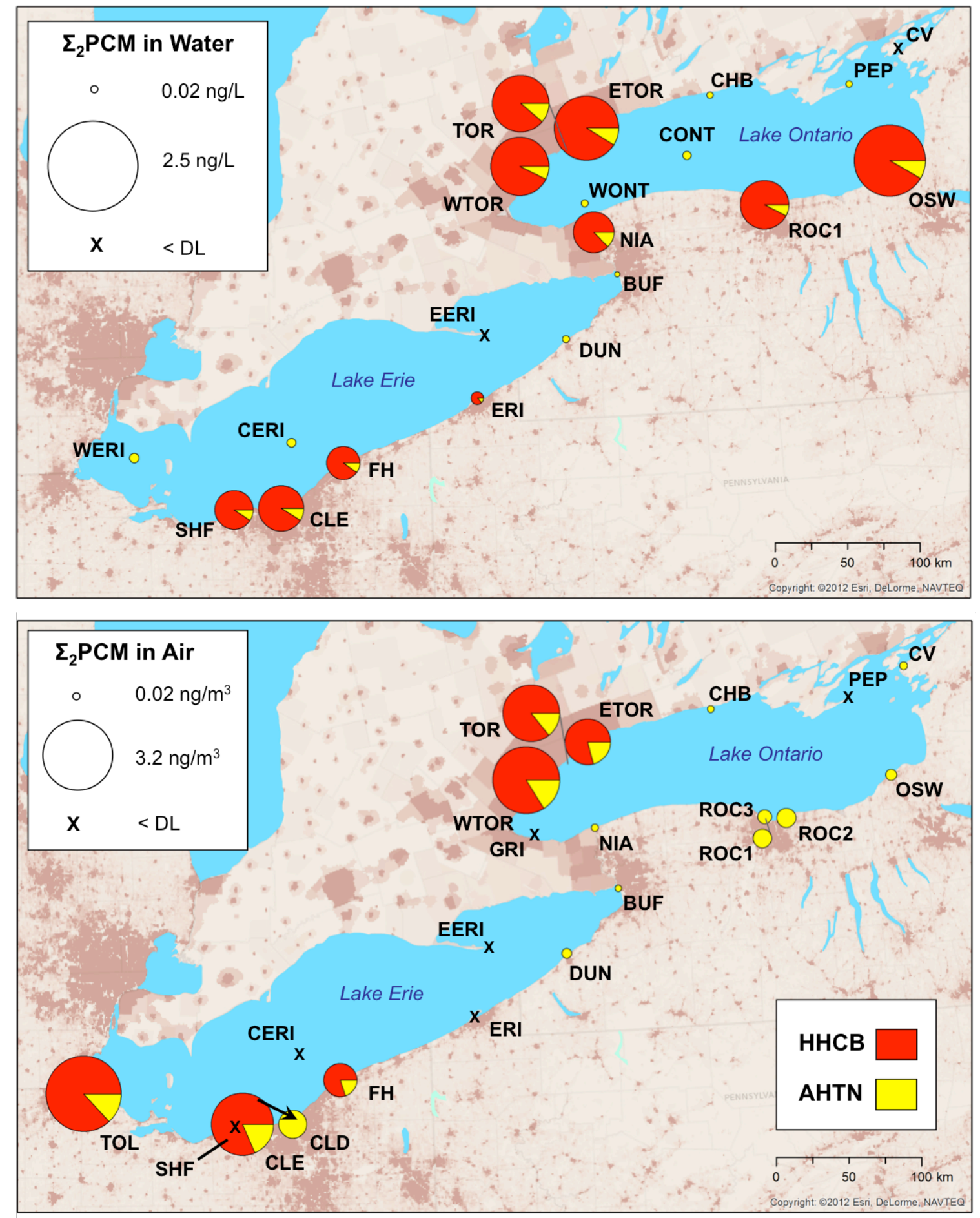

598 Figure 1. Average summer HHCB and AHTN $\left(\boldsymbol{\Sigma}_{\mathbf{2}} \mathbf{P C M}\right)$ concentrations throughout the 599 lower Great Lakes. Average dissolved (top) and gaseous (bottom) HHCB and AHTN during 600 summer deployments are shown with HHCB in red and AHTN in yellow. Gaseous $\Sigma_{2}$ PCM 601 ranged from $<\mathrm{DL}$ at sites marked by X's to $3.2 \mathrm{ng} / \mathrm{m}^{3}$ in Toledo (TOL). Dissolved $\Sigma_{2} \mathrm{PCM}$ 602 ranged from <DL at sites marked by X's to $2.5 \mathrm{ng} / \mathrm{L}$ near the mouth of Oswego River (OSW). 

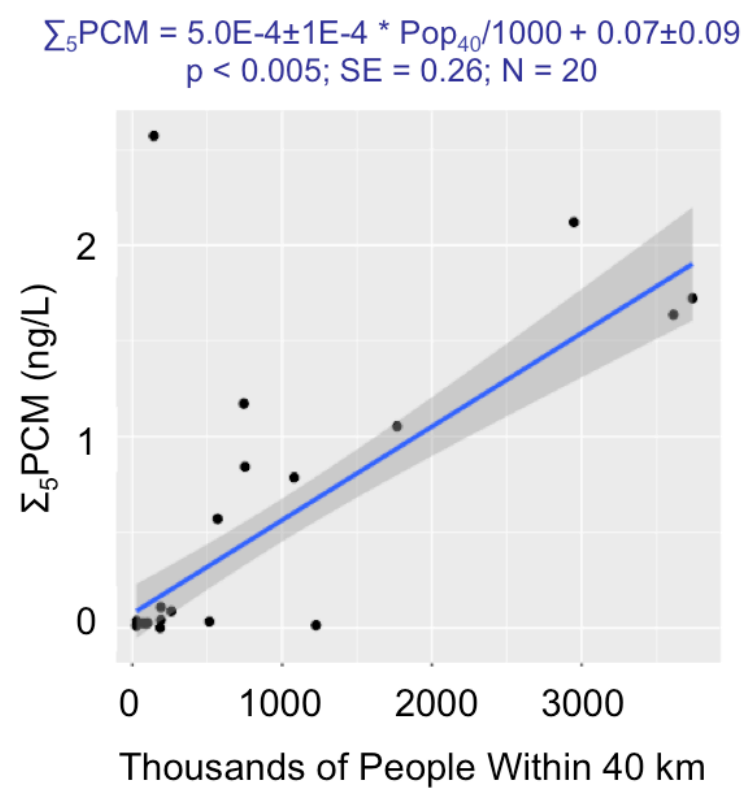

$\sum_{5} \mathrm{PCM}=1.1 \mathrm{E}-3 \pm 1 \mathrm{E}-4{ }^{*} \mathrm{Pop}_{25} / 1000-0.12 \pm 0.12$ $\mathrm{p}<0.001 ; \mathrm{SE}=0.33 ; \mathrm{N}=22$

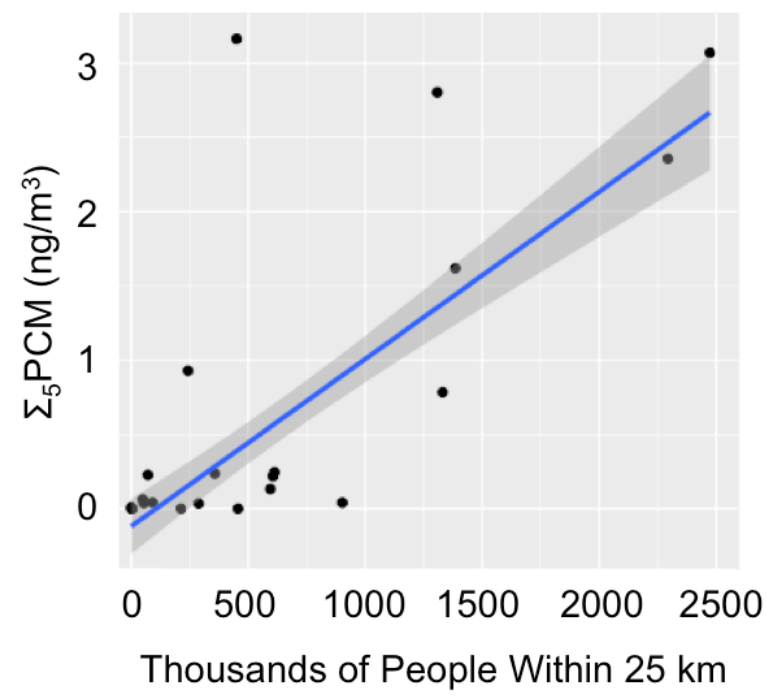

604 Figure 2. Correlation of dissolved and gaseous $\Sigma_{5} \mathbf{P C M}$ and surrounding population 605 density. Average summer dissolved (left) and gaseous (right) $\Sigma_{5} \mathrm{PCM}$ was most strongly 606 correlated with population within $25 \mathrm{~km}$ and $40 \mathrm{~km}$ of each site, respectively. 95\% confidence 607 intervals for the linear models are shaded in gray.

608

609

610 
Concentration in Water

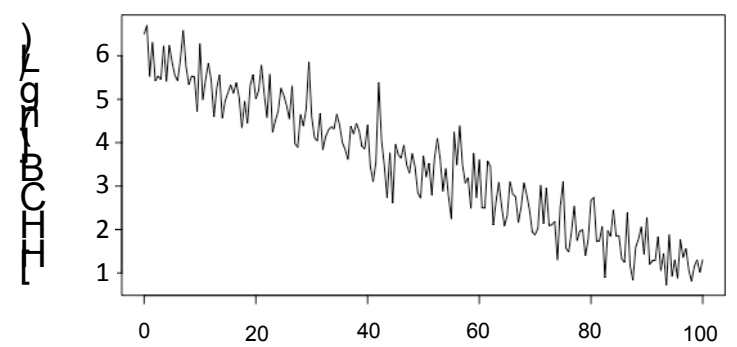

Concentration in Air
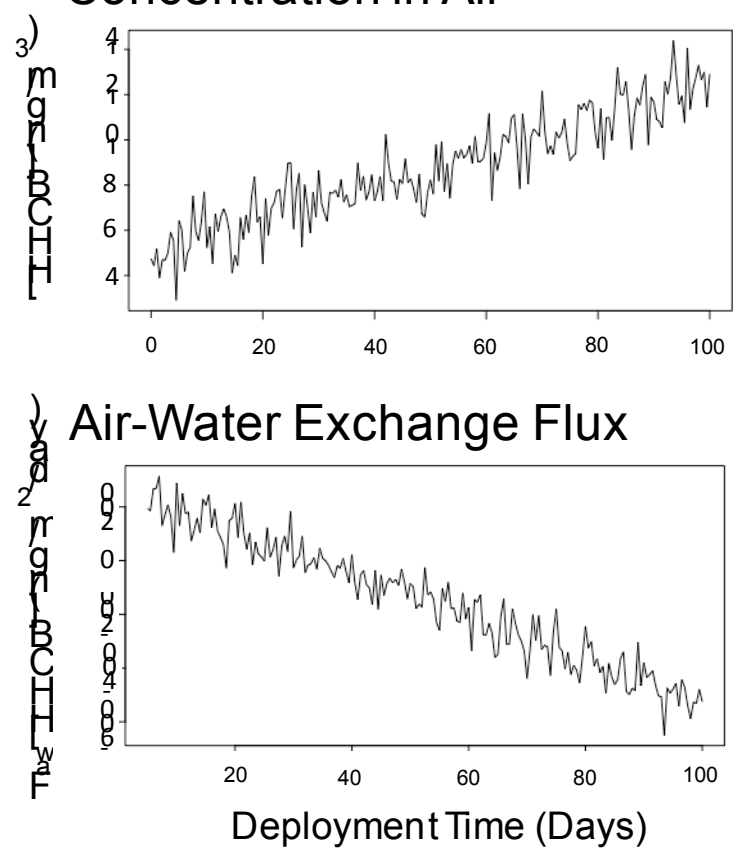

\section{Mass in Water PE}

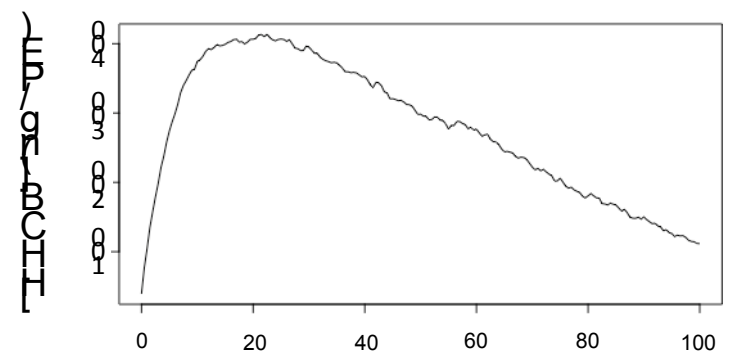

Mass in Air PE

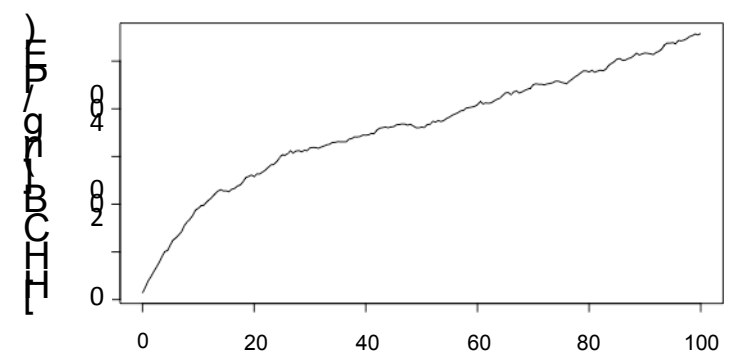

PE-Derived A/W-Exchange Flux

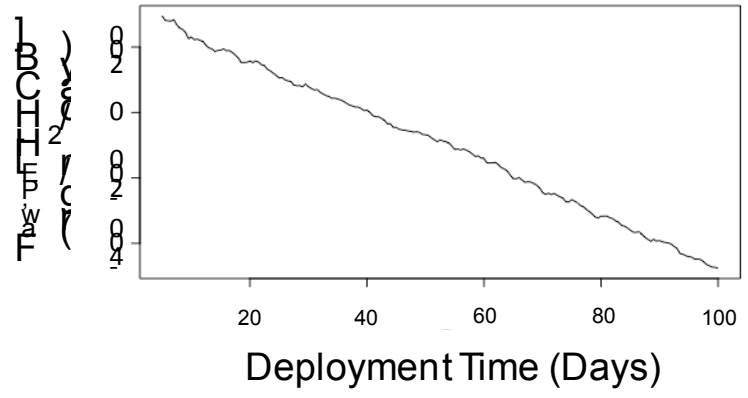

Figure 3. Predicted Air-Water Exchange Fluxes Based on Simulated Air and Water HHCB Concentrations. Simulated water and air concentrations of HHCB and air-water exchange fluxes calculated from these concentrations are shown on the left over a 100-day simulated be calculated using this pair of air and water PEs. 
624 Table 3. Comparison of Simulated Air-Water Exchange Fluxes to PE-Derived and Grab

625 Sample-Derived Exchange Fluxes.

\begin{tabular}{|l|c|c|}
\hline & $\begin{array}{c}\text { Scenario 1: Randomly } \\
\text { Fluctuating Air and Water } \\
\text { Concentrations }\end{array}$ & $\begin{array}{c}\text { Scenario 2: Steadily Increasing } \\
\text { Air and Decreasing Water } \\
\text { Concentrations }\end{array}$ \\
\hline \multicolumn{3}{|c|}{ Relative Percent Difference (RPD) between $\mathrm{F}_{\mathrm{aw}}$ and $\mathrm{F}_{\mathrm{aw}, \mathrm{PE}}$} \\
\hline Mean $\mathrm{F}_{\mathrm{aw}}$ Over 100 Days & $18.5+/-6.8 \%$ & $357+/-267 \%$ \\
\hline Mean $\mathrm{F}_{\mathrm{aw}}$ Over Last 22 days & $15.3+/-8.8 \%$ & $8.4+/-5.2 \%$ \\
\hline $\mathrm{F}_{\mathrm{aw}}$ on Day 100 & $351+/-219 \%$ & $12.3+/-1.2 \%$ \\
\hline \multicolumn{2}{|c|}{ Relative Percent Difference (RPD) between $\mathrm{F}_{\mathrm{aw}}$ and mean $\mathrm{F}_{\mathrm{aw}}$ from weekly grab sample } \\
\hline Mean $\mathrm{F}_{\mathrm{aw}}$ Over 100 Days & $26.9+/-15.0 \%$ & $21+/-15 \%$ \\
\hline Mean $\mathrm{F}_{\mathrm{aw}}$ Over Last 22 days & $60.4+/-34.6 \%$ & $329+/-232$ \\
\hline
\end{tabular}

626

627

628

629 


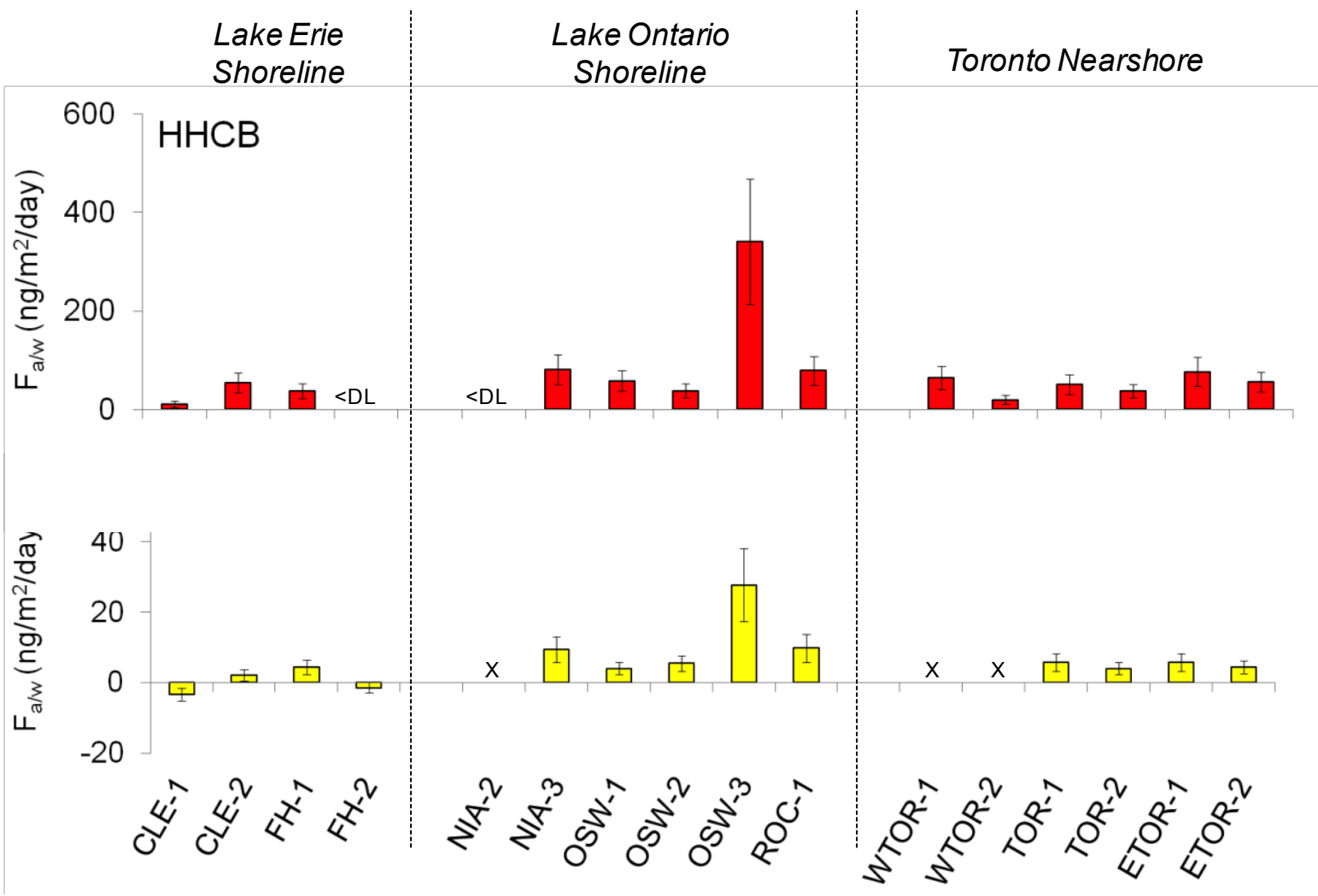

631 Figure 4. Summer air-water exchange fluxes of AHTN and HHCB. Air-water exchange

632 fluxes are shown for shoreline Lake Erie and Lake Ontario sites, as well as nearshore Toronto 633 buoy sites. Positive bars represent volatilization while negative bars represent absorption. Cases 634 where both air and water concentrations were $<$ DL were marked " $<$ DL". Cases where fugacity 635 ratios were not significantly different from equilibrium were marked " $X$ ". Offshore Lake Erie 636 and nearshore northern Lake Ontario sites as well as some shoreline sites (SHF, ERI, DUN, 637 BUF, and CV) were omitted because no significant exchange fluxes were calculated there. Error 638 bars represent standard deviation calculated via error propagation. 
644 GRAPHICAL ABSTRACT

645

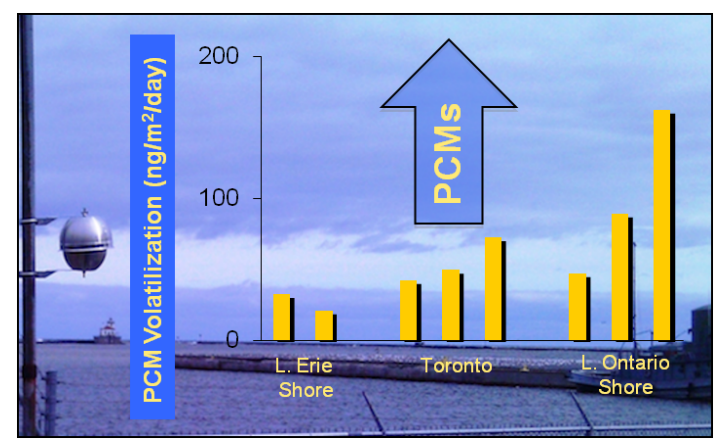

646 For Table of Contents only

647 